\title{
Rackla pluton geothermal gradient: implications for mineral exploration
}

\author{
M.E. REGO ${ }^{1}$, D. GREGORY ${ }^{1}$ \\ ${ }^{1}$ Department of Earth Sciences, University of Toronto, \\ Toronto, Ontario, Canada
}

The Rau project is operated by ATAC Resources Ltd., and is the site of the Tiger deposit, a carbonate replacement intrusion related gold deposit. This study aims to define the extent of the hydrothermal system surrounding the Rackla pluton, a mid-cretaceous granitic intrusion, hosted in dolostone and shale of the Selwyn Basin, Yukon, Canada. Geochemical and fluid inclusion analyses are focused on mineral targets adjacent to the Tiger deposit, which may be related to a broader mineralized system.

Skarns are a subset of intrusion related ore deposit, characrterized by calc-silicate gangue mineral assemblage. The dominant ore minerals of a skarn deposit are commonly zoned along thermal and compositional controls. There is evidence for progression of various styles of skarn mineralization with distance from the intrusion, consistent with other zoned skarn systems globally. The presence of molybedenite proximal to the known intrusion, and progressively more distal chalcopyrite and sphalerite are believed to reflect this zonaton.

The fluids of a hydrothermal system may be trapped in growing minerals, and are often preserved unaltered in fluid inclusions. When heated, immiscible phases homogenize at a temperature which may reflect the trapping temperature. This method of microthermometry, combined with calc-silicate geochemistry, and an independent geothermometer will help to define the relationship of skarn targets to the thermal and compositional evolution of the Rackla pluton and its related hydrothermal system. With this information there may be more effective exploration at the Rau property and similar mineral occurances elsewhere as skarn and other intrusion related ore deposits are better understood. 